\title{
Smoking Abstinence in Patients Scheduled for Elective Surgery
}

\begin{abstract}
Smokers have an increased risk of perioperative and postoperative complications, including a higher incidence of airway and respiratory, cardiovascular events, and impaired wound healing. This brief review will remind anesthesiologist and surgeons that their preoperative smoking intervention for smoking cessation can be effective in decreasing the incidence of complications. Preoperative smoking intervention, even if it is both brief and intensive, may help to decrease this risk. The surgical event is the important 'teachable moment' that could translate, with proper smoking intervention, into permanent smoking cessation.
\end{abstract}

\section{KEY WORDS}

Tobacco smoking, preoperative smoking intervention, smoking cessation, elective surgery.

DOI: $10.7251 / S M D 1302097 S$

(Scr Med 2013;44:97-9)

\section{Nataša Stojaković, Živojin S. Jonjev, ${ }^{2}$ Rajko Igić1,3}

${ }^{1}$ Department of Pharmacology and Clinical Pharmacology, Medical Faculty, University of Banja Luka, Republic of Srpska, Bosnia \& Herzegovina

${ }^{2}$ Institute for Cardiovascular Diseases of Vojvodina, Clinic of Cardiovascular Surgery, University of Novi Sad, Serbia

${ }^{3}$ Department of Anesthesiology and Pain Management, John Stroger Hospital, Chicago, Illinois, USA

\section{Correspodence}

Rajko Igić, M.D., Ph.D.

Department of Anesthesiology and Pain Mangement

John Stroger Hospital of Cook

County, Chicago, IL 60612, USA

E-address: rigić@excite.com

Submitted: April 3o, 2012

Accepted: September 15, 2013
Cigarette smokers have an increased risk of perioperative and postoperative complications, such as higher incidence of airway and respiratory (e.g., reintubation, laryngospasm, bronchospasm, and hypoventilation), cardiovascular events, and impaired wound healing. ${ }^{1,2}$ Preoperative smoking intervention may be effective in decreasing the incidence of such risk, and surgery may constitute a unique opportunity for permanent smoking cessation. In this short article, we present the reasons why the physicians, anesthesiologists and surgeons should regularly perform interventions for preoperative smoking cessation.

\section{Background}

Tobacco smoking has many effects on heart function and circulation, both in the short and the long term. ${ }^{1}$ Short/ term effects are mainly due to increased carbon monoxide (CO) and nicotine in the blood. These substances persist as long as 24 to 48 hours after smoking cessation. The harmful action of carbon monoxide relates to the reduction by $3-12 \%$ of oxygen delivery to the tissues where $\mathrm{CO}$ binds to the hemoglobin molecules instead of oxygen. Nicotine stimulates the stress response to surgery, resulting in increased blood pressure, pulse rate and systemic vascular resistance, thus increasing the work of heart. It was recently shown that nicotine replacement therapy (NRT) causes a limited vasoactive effect only when administered intravenously. ${ }^{1}$ The long-term effects of smoking include the development of generalized atherosclerotic changes in the vasculature. Short-term effects of smoking are more important in smokers who suffer from generalized atherosclerosis.

Smoking presents a higher risk of serious postoperative complications, such as pneumonia and respiratory failure due to impaired cilliary function, increased mucus production, and the damage to immune responses within the lung. Smoking can also cause impaired bone and surgical wound healing, as a result of decreased immune function and tissue oxygenation from vasoconstriction and carboxyhemoglobin formation. ${ }^{3}$

While smoking clearly increases the risk for perioperative complications, recent publications suggest that even short term preoperative smoking cessation can reduce the risk of postoperative cardiovascular and pulmonary complications and improve post/surgical outcomes. ${ }^{4,5}$ Evidence from two trials indicates that interventions beginning four to eight weeks before surgery with weekly counseling and NRT, support smoking cessation and reduce complication rates. ${ }^{1,4}$, Brief interventions support short-term smoking cessation, but there is insufficient evidence to determine whether they reduce complications. This may be due to the 
longer period of pre-operative abstinence achieved when interventions begin four to eight weeks before surgery.

\section{Pre-and Post-operative Interventions}

Brief or more intensive intervention, including both behavioral and pharmacological strategies, with or without face-to-face contact, should be applied at least 48 hours before an elective surgical operation. ${ }^{6,7}$ Despite evidence that preoperative smoking cessation promotes favorable surgical outcomes, the clinical staff directly involved in perioperative care may not be adequately equipped to deliver standardized cessation education. They may not be trained to understand the challenges smokers encounter when attempting to quit. Thus, a multidisciplinary approach with physicians delegating smoking cessation counseling to peer educators may prove more effective, especially in socially disadvantaged populations.

Brief Intervention. The doctors should advise patients according to the usual protocol: Asking about tobacco history, Advising smoking cessation before surgery and Presenting basic health information. Optimally, this AAP advice also includes a written handout detailing the major health benefits to cessation (e.g., cardiovascular, lung health, wound healing, and cancer risk reduction) and the timeframe within which these benefits occur.

Intensive Intervention. An intensive smoking cessation intervention may have a longer introductory session with the opportunity to ask and respond to questions about risks, benefits and strategies. The intake nurse should refer the patient to an educator who will assess smoking status and offer individualized counseling. The health educator should inform the anesthesiologist of the patient preference (attempt to quit, cut back, or make no change at the present time). For those patients who want to quit smoking and who smoke six or more cigarettes a day, the anesthesiologist may prescribe medications (Table 1). For those who smoke 6-9 cigarettes/day, a single medication should be offered. For those who smoke 10 or more cigarettes per day, the anesthesiologist may offer a combination of a long acting agent (either bupropion or nicotine patches) with a short acting nicotine replacement (lozenge). Bupropion and/or nicotine patches ${ }^{8}$ would be provided during the entire preoperative period. The quit date should be coordinated with the use of the medication. The patient may be encouraged to sign a declaration of commitment not to smoke preoperatively as a motivated reminder. This declaration should be signed by both the patient and doctor (anesthesiologist or surgeon) simultaneously.

Some patients are nervous immediately prior to and after surgery and they often wish to smoke during that period. Yet many of them are able to avoid smoking after anesthesia and surgery with the support of an intervention. However, a brief smoking intervention may not be powerful enough to influence heavy smokers; these highly dependent individuals may require more intensive intervention.

For patients who ceased to smoke preoperatively, the educator should focus on prevention of relapse in the postoperative phase. The educator should meet face-to-face with participants during a postoperative surgical clinic appointment, generally within 1-2 weeks following surgery. The counseling message must be tailored according to the patient's motivation and related to the behavioral change achieved during the preoperative phase. Telephone counseling may be scheduled following the postoperative clinic.

Millions of patients worldwide undergo surgery each year. The rate of smoking in surgical patients is higher than in the general population. Consistent and significant improvement in preoperative quit rates and postoperative morbidity has been achieved through interventions among heterogeneous populations in the UK, Europe and Australia. Several studies of intensive preoperative cessation intervention indicate improved health both at the time of surgery and during a 12-month postoperative period, as well as decreased post-operative complications. ${ }^{9-12} \mathrm{How}$ ever, brief interventions failed to increase the long-term cessation benefits. The surgical event is the important 'teachable moment' that could translate into permanent smoking cessation if adequate support is available from clinical personnel. Perhaps even the hard-core smokers need a doctor's support to realize and benefit from such an opportunity.

\section{Epilogue}

Despite long lasting and intensive campaigns against tobacco use in many countries, including a successful campaign of Yugoslav medical students, ${ }^{13}$ cigarette smoking remains one of the greatest public heath threats. It is an

Table 1. Pharmacologic interventions that assist smoking cessation during the preoperative period and/or during the initial postoperative period.

\begin{tabular}{llll}
\hline Drug $^{*}$ & Dose & Duration & Side effects \\
\hline Nicotine patch & $7-21 \mathrm{mg} /$ day & 8 weeks & Erythema, pruritus \\
\hline Nicotine lozenge & two to eight lozenges of $2 \mathrm{mg} /$ day & 8 weeks & Sore throat, heartburn \\
\hline Bupropion (Zyban) & $150 \mathrm{mg} /$ day x 2 days, then $300 \mathrm{mg} /$ day & $8-12$ weeks & Insomnia, dry mouth, dizziness, rhinitis \\
\hline
\end{tabular}

\footnotetext{
*Some of these medications are not available in many developing countries.
} 
especially prevalent heath problem in many developing countries, including all of the Balkan states. Approximately 70 percent of smokers annually express an interest in quitting, but only about five percent achieve sustained cessation. Several systematic reviews report that simple, one time advice from a physician during a routine consultation increased the number of smokers who quit and did not relapse for one year. ${ }^{1}$ Published reviews also suggest that advice from trained counselors were more effective in increasing quit rates than a minimal intervention. Interventions aimed at changing smoker's behavior should thus be exploited before elective surgery.

\section{Authorship statement \\ All authors contributed equally.}

\section{Financial disclosure}

We declare that we have no conflicts of interest.

\section{References}

1. Thomsen T, Villebro N, Møller AM. Interventions for preoperative smoking cessation. Cochrane Database of Systematic Reviews 2010, Issue 7. Art. No.: CDoo2294. DOI: 10.1002/14651858.CDo02294.pub3.

2. Silverstein P. Smoking and wound healing. Am J Med 1992;93:22S-3S.

3. Turan A, Mascha EJ, Roberman D, et al. Smoking and Perioperative Outcomes. Anesthesiology 2011;114: 837-46.

4. Moores LK. Smoking and postoperative pulmonary complica- tions: an evidence-based review of the recent literature. Clin Chest Med 2000; 21: 139-46.

5. Warner, DO. Tobacco Dependence in Surgical Patients. Curr Opin Anaesthesiol. 2007;20(3):279-83.

6. Moores LK. Smoking and Postoperative Pulmonary Complications: An Evidence-based Review of the Recent Literature. Clin Chest Med. 2000;21(1):139-46.

7. Møller AM, Villebro N, Pedersen T, Tønnesen H. Effect of preoperative smoking intervention on postoperative complications: a randomised clinical trial. Lancet 2002;359(9301):114-7.

8. Tovey D, ed. Clinnical evidence concise. London, BMJ Publishing Group, 2005

9. Sorensen LT, Karlsmark T, Gottrup F. LT Sorensen, T Karlsmark, and F Gottrup, Abstinence from smoking reduces incisional wound infection: a randomized controlled trial. Ann Surg. 2003;238(1):1-5.

10. Lindström D, Sadr Azodi O, Wladis A, et al. Effects of a Perioperative Smoking Cessation Intervention on Postoperative Complications: A Randomized Trial. Ann Surg. 2008;248(5):739-45. doi: 10.1097/SLA.obo13e3181889dod.

11. Sadr Azodi O, Lindström D, Adami J, et al. The efficacy of a smoking cessation programme in patients undergoing elective surgery: a randomised clinical trial. Anaesthesia. 2009 Mar;64(3):259-65. doi: 10.1111/j.1365-2044.2008.05758.x.

12. Jha $P$, Ramasundarahettige $C$, Landsman $V$ et al. $21^{\text {st }}$ century hazards of smoking and benefits of cessation in the United States. N Engl J Med 2013;368:341-50. doi: 10.1056/NEJMsa1211128.

13. Zizic-Borjanovic S, Jerinic M, Igic R. Twenty five years of antismoking movement started by medical students: some further goals. J BUON 2007;12:181-4.

\title{
Apstinencija od pušenja kod pacijenata predviđenih za elektivne hirurške zahvate
}

\begin{abstract}
APSTRAKT
U pušača postoji povećan rizik od postoperativnih komplikacija, uključujući povećanu incidencu vazdušnih i respiratornih, kao i kardiovaskularnih događaja te usporenog zarastanja rana. Ovaj kratki članak bi trebalo da podsjetiti anesteziologe i hirurge na značaj preoperativne intervencije u vezi sa prestankom pušenja u smanjenju incidence komplikacija. Preoperativana intervencija za prestanak pušenja, makar kratka i intenzivna, može doprinijeti smanjenju rizika. Operativni zahvat je važan „ključni momenat“ koji, uz prikladnu intervenciju, može učiniti da pacijent trajno prestane da puši.
\end{abstract}

\section{KLJUČNE REČI}

Pušenje duvana, preoperativna intervencija, prestanak pušenja, elektivni hirurški zahvat. 